\title{
PRESENT SCENARIO OF ELECTRIC VEHICLES IN INDIA
}

\author{
Shyam Patidar \\ Assistant Professor, Department of Mechanical Engineering \\ S.V.I.T.S. Shri Vaishnav Vidyapeeth Vishwavidyalaya, \\ Indore, M.P. India
}

\begin{abstract}
India is one of the largest automobile market in the world. Due to large numbers of automobiles are being used and growing sales of automobiles year-on-year. The fuel consumption increasing due to rising number of automobiles and energy demand of India; it is raising dependency on oil imports, expenses of foreign oil imports, emission issues etc. This all needs a sustainable mobility solution. Electric vehicles (EVs) are aligned with emobility and economic goals of the nation and strategic goal to reduce foreign crude oil dependency as well as emission/environmental issues. To mitigate the effects of global warming and the real solution can be provided by EVs. This paper highlights the present scenario and progress of EVs in India.
\end{abstract}

Keywords - Electric Vehicle, Automobiles, e-Mobility, Energy, Battery, e-Bus.

\section{INTRODUCTION}

Automobiles are very important for transformation of any country and transports of logistics and public. In India, crores of vehicles are being used and it's increasing every year. The sources of oil and its exploration in India are limited. To fulfil the fuel demand India imports crude oil from the many other countries. Due to the limited sources of convention automotive fuels as well as many global issues related to its exploration and distribution; it impacts on the cost of crude oil. Due to dependency on foreign crude oil imports and fluctuating oil price is giant issue. Indian automotive sector is one of the large and rising sector [1]; hence it affects Indian economy too. India is also looking to reduce its dependency on foreign crude oil and its expenses. Emission from the conventional fuels is also a challenging issue all over the world. As increasing transportation needs and population in India; it needs more automobiles year and year. These issues can be comprehensively control by electrical vehicles. The specialities of the EVs are free from emission and environmental friendly.

\section{ELECTRIC VEHICLES}

Battery electric vehicle (BEVs) gets power directly from the battery and run an electric motor; which runs the automobile. It is an alternative of conventional fuels such as petrol, diesel or gas etc. Also, it is environment friendly because has zero emissions [2]. Another good substitute is Hybrid electric vehicles (HEVs) for near future, whenever the full flashed charging infrastructure is not developed for pure electric vehicle. HEV is the combination of a conventional internal combustion engine (ICE) system and electric propulsion system. HEV offers better fuel economy and lower emission than conventional ICE [3, 4]. Plug-in HEVs (PHEVs) has an additional feature to charge at power station. In PHEVs battery is act as main power source while ICE is secondary power source [5]. The third one is the REEV (Range Extended Electric Vehicle) or Extended Range EVs (EREV) driven by electrical motor and the power supplied by high capacity batteries [6]. Small generator unit arrangement is within the vehicle for charging these batteries. Fuel cell electric vehicle (FCEV) is run by motor supplying electricity; which is generated by fuel cells using fuels directly. It works on principle of electrochemical energy conversion [7]. Another one is solar electric vehicles (SEV); which produce electricity often by photovoltaic cells [8].

\section{GOVERMENT INITIATIVES TO PROMOTE EVS}

India is dependent on foreign crude oil; to fulfil its energy demand of industries and automotives. To strengthen energy security and sustainable development in country; Indian government has taken many initiatives to promote and increase use of biofuel $[9,10]$ and manufacturing and developing EV's and desirable infrastructure [11].

In 2013, Indian government commenced National Electric Mobility Mission Plan-2020 (NEMMP-2020) under this mission a scheme called Faster Adoption and Manufacturing of (Hybrid \&) Electric Vehicles in India (FAME-India) launched to promote EV technology. Under the FAME-India scheme Indian government had provided all the necessary support the respective industry for the development of EV market and ecosystem to manufacture HEVs/BEVs by 2020 [11]. In 2014, government announced Deen Dayal scheme; which helps in financing and procurement of eRickshaws. Also, the amendment in motor vehicle act in 2015 made for e-Rickshaws to establish as valid commercial transport. 


\section{International Journal of Engineering Applied Sciences and Technology, 2019 Vol. 4, Issue 8, ISSN No. 2455-2143, Pages 106-108 \\ Published Online December 2019 in IJEAST (http://www.ijeast.com)}

As per the NITI Aayog's transformative mobility report-2017; it has set out a roadmap with taregt for pure electric vehicle and it is stated that there will be $100 \%$ public transport vehicles and $40 \%$ of private vehicle become pure electric by 2030 [12].

"The Society of Indian Automobile Manufacturers (SIAM)" together with its automobile manufacturers aspires to reach all new vehicles sales within the country to be $100 \%$ pure EVs (BEVs or FCEVs) on India's hundredth anniversary of Independence (2047) [12].

\section{PRESENT SCENARIO OF EVS IN INDIA}

There are several e-vehicles presently providing transport services in various parts of the country. In order to that first e-bus was launched in 2014 at Bangalore; which was the zero-emission Chinese-made BYD bus. Then after, Ashok Leyland launched first made-in-India electric bus in October 2016. Later on, Tata motors launched his fully electric (Ultra Starbus Electric 9m) and a hybrid (Starbus Electric 12m) bus in January 2017 at his Pune facility. In September 2017, Goldstone Infratech Ltd supplied 25 electric buses $(25+1$ seater Goldstone eBuzz K7) to Himachal Pradesh Transport Corporation. In March 2018, Tata Motors were delivered 25 Tata starbus hybrid buses in Mumbai, Maharashtra. Intercity e-buses services are already been started in states such as Kerala, Himachal Pradesh and Maharashtra from year 2019. Electric bus for public transport in some of the cities of India such as New Delhi, Mumbai, Kolkata, Bangalore, Lucknow, Indore, Hyderabad, Manali etc. are already using and many cities will have the e-buses in upcoming years.

The first electric car (hatchback e2o) is launched (March-2013) in India by Mahindra. Presently, there are many electric cars available in India are Hyndai Kona, Mahindra e2oplus, Mahindra e-varito, Tata tigor EV and many more have to be launched in 2020. Several hybrid cars in India are Honda accord, Toyota camry, Totota glanza, Toyota Prius, BMW 7 seriese, MG hector etc. Many e-rickshaws, mini electric pickups/trucks and electric motorcycles are already being used in India.

\section{CONCLUSION}

The demand of conventional fuel in India and money spend on the import of crude oil is increased in previous years [13]. It is raising expenses of foreign oil imports and dependency on import crude oil, emission issues etc. Due to energy dependency on foreign crude oil, it impacts to Indian energy security and economy too. Also, fluctuating price of crude oil is challenging issue for India. Indian government has taken many steps to transform its transportation from convention one to towards e-mobility. India is now positively moving and growing towards e-mobility through its policies. In many cities of India started e-bus and hybrid buses for public transport in the cities as well as for intercity transport and many more cities of India in the row to start the same. Many electric cars available in India and its sales increased in recently. As per NITI Aayog's roadmap and target; $100 \%$ public transport and $40 \%$ of private vehicles will be pure electric by 2030. SIAM has expected to achieve the $100 \%$ sales of EVs on India's hundredth anniversary of Independence (on Aug. 15, 2047). If, India succeeds to achieve its set e-mobility target within time frame, it shall result in reduce crude oil dependency, strengthen its energy security, control carbon emission/pollution in urban areas, control/reduce a current account deficit etc. There are several challenges for the nation to achieve the e-mobility target such as affordable price of EVs, charging infrastructure, battery/cell manufacturing, taxes/ government regulation challenges, public awareness etc. The transformation towards e-mobility is necessity for sustainable transportation; diminish the global carbon emission and many other economical and social challenges of India.

\section{ACKNOWLEDGEMENT}

I acknowledge all authorities of Shri Vaishnav Vidyapeeth Vishwavidyalaya, Indore (M.P) for the support and providing the necessary facility to complete this work. Also, I am grateful to my friends, colleagues and family for their constructive comments and suggestions.

\section{REFERENCES}

[1] Patidar Shyam and Chourasiya Rupesh (2018) "Supply Chain Challenges for Indian Automotive" International Journal for Research in Applied Science \& Engineering Technology (IJRASET), Vol. 6 Issue VI, pp. 1735-1737.

[2] Patidar Shyam (2018) "Alternative Fuels For Automobiles" EPRA International Journal of Research and Development, Vol. 3. Issue 12, pp. 159-162.

[3] He Y., Venkatesh B. and Guan L. (2012) "Optimal Scheduling for Charging and Discharging of Electric Vehicles", IEEE Trans. on Smart Grid, vol.3, no.3, pp. 1095-1105.

[4] Xin L. and Williamson S. S. (2007) "Assessment of Efficiency Improvement Techniques for Future Power Electronics Intensive Hybrid Electric Vehicle Drive Trains" in Electrical Power Conference-2007. EPC 2007. IEEE Canada, pp. 268-273.

[5] Wu J., Emadi A., Duoba M. J. and Bohn T.P. (2007) "Plug-in Hybrid Electric Vehicles: Testing, Simulations, and Analysis", Vehicle Power and Propulsion Conference, pp: 469-476, September 2007.

[6] Rosario L., Luk P. C. K., Economou J. T. and White B. A. (2006) "A Modular Power and Energy Management 


\section{International Journal of Engineering Applied Sciences and Technology, 2019 \\ Vol. 4, Issue 8, ISSN No. 2455-2143, Pages 106-108 \\ Published Online December 2019 in IJEAST (http://www.ijeast.com)}

Structure for Dual-Energy Source Electric Vehicles", IEEE Vehicle Power and Propulsion Conference, pp:1-6.

[7] Lai J. and Nelson D. J. (2007) "Energy Management Power Converters in Hybrid Electric and Fuel Cell Vehicles" in Proceedings of the IEEE, vol. 95, no. 4, pp. 766-777. (10.1109/JPROC.2006.890122)

[8] Chen H., Lu F. and Guo F. (2012) "Power Management System Design for Small Size Solar Electric Vehicle" IEEE $7^{\text {th }}$ International Power Electronics and Motion Control Conference - ECCE Asia-2012, pp. 2658-2662.

[9] "National Biofuel Policy-2018" the gazette of India, REGD. NO. $\quad$ D. $\quad$ L.-33004/99 (http://petroleum.nic.in/national-policy-biofuel-2018-0)

[10] Patidar Shyam (2018) "Recent Scenario of Biofuels in India" EPRA International Journal of Research and Development, Vol. 3. Issue 12, pp. 192-194.

[11] "NEMMP-2020" Dept. of Heavy Industry, Ministry of Heavy Industries and Public Enterprises, Govt. of India (https://dhi.nic.in/writereaddata/Content/NEMMP2020.pd f)

[12] "Adopting Pure Electric Vehicles: Key Policy Enablers" White Paper on Electric Vehicles by Society of Indian Automobile Manufacturers (SIAM), Dec. 2017. (http://www.siam.in/uploads/filemanager/114SIAMWhite PaperonElectricVehicles.pdf)

[13] "Annual report 2017-18" Ministry of Petroleum and Natural Gas, Govt. of India (http://petroleum.nic.in). 